\title{
The Significance of Tu Gelu Traditional Medical Treatment: Sociological Case of the Lio People at Ngalukoja Village, Ende Regency, East Nusa Tenggara, Indonesia
}

\author{
Zainur Wula*, Idris Mboka \\ Department of Sociology, Universitas Muhammadiyah, Kupang, Indonesia
}

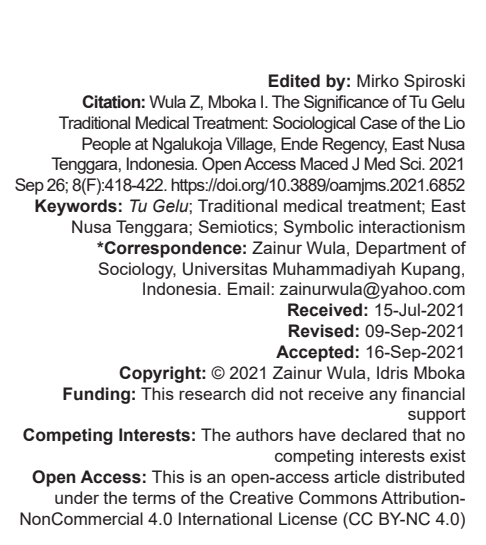

\begin{abstract}
This study aims to describe the meaning of $t u$ gelu in the traditional medical treatment of Lio people in Ngalukoja Village, Ende Regency, East Nusa Tenggara Province, Indonesia. Tu gelu is a traditional healing method carried out by the Lio people by exchanging items that symbolize cattle such as bulls or pigs, to heal a person who is sick from supernatural disturbances or from fever. This method is mediated by a shaman, who carries out several stages in the healing process. It includes paga (where the shaman measures his chest to his right hand using the span of his left hand) to know the cause of the sickness. This is a descriptive qualitative research with the phenomenological paradigm. It uses the snowball technique to acquire information from informants. It uses symbolic interactionism and semiotics to analyze the research objects. The results show that from the symbolic interactionism analysis, material symbols are exchanged with the patient's health. The semiotic theory shows that the figures serve as icons; kitchen ash, chicken feather, and spells serve as indexes; finally, the items prepared as the offerings to the genie serve as symbols. The Ngalukoja villagers of East Nusa Tenggara believe that using the tu gelu healing method that contains various signs, the patient will fully revive from the illness.
\end{abstract}

\section{Introduction}

In some rural areas of Indonesia, even though health facilities exist, people still undergo traditional healing methods using mystical and supernatural powers via shamans [1]. Foster and Anderson [2] classify this type of traditional healing into two: (1) personalistic treatment and (2) naturalistic treatment. The former views diseases as results from the intervention of an active agent such as supernatural beings or humans who apply witchcraft, meanwhile the latter acknowledges an equilibrium model, where health is achieved due to the balance of certain elements in the body. This Foster Dichotomy is generally accepted as a method to see the healing system tendencies of a certain community, though in many cases, communities embrace double etiology, where diseases are caused by both personalistic and naturalistic factors.

The Lio people of Ngalukoja Village, Ende Regency, Flores Island, East Nusa Tenggara Province, Indonesia, tend to visit the village shaman (ata mbeo) to heal diseases. The centuries-old healing method is called tu gelu, literally meaning "to exchange." Here, the ill provide non-verbal symbols that resemble cattle, meanwhile, the shaman say monolog spells (verbal symbols) directed to genies or ancestral spirits to heal the patient. They collect little to no fee for their services. This tu gelu is a culture of the Lio people. According to Soekanto [3], community work results in technologies, beliefs, or material culture that are necessary for humans to have control over the nature around them, so that the results may be eternalized for their sake.

The symbols of a culture are a vehicle of conception that results in intellectual elements in a social process. Barker [4] states that there are symbols in cultures that serve as a guideline or an intended purpose. Symbols are synonymous with signs or language, and as Hoed [5] stated, a language is a communication tool of a society that uses a system of signs, whose meanings are conventionally understood by its members. In a social context, individuals try to anticipate other people's actions and adapt their behaviors according to how they interpret those actions. This is called the self-indication process [6]. According to Blumer [7], in an interaction, individuals are bridged by the usage of interpretation symbols, namely language. This paper uses symbolic interactionism to analyze the object.

This paper also uses the semiotic theory to analyze the object. It studies the signs that exist in society [8]. Pierce asserts signs as representamens 
and concepts that are referred to as objects. The significance (impression, feelings, etc.) of a sign is called interpretant (Figure 1).

Representamen $(\mathbf{X})$

Figure 1: The triangle meaning theory

Peirce in Danesi [9] asserts the triangle meaning theory, where the elements are a sign, object, and interpretant. A sign is a material thing that may be captured by the senses. It represents something beyond itself. Signs consist of symbols (a sign that emerges from an agreement), icons (a sign that emerges from physical representation), and index (a sign that emerges from a causality effect). An object is a reference to these signs. Interpretants are those who use these signs. The most important part of the semiosis process is how significance emerges from a sign when that sign is used during communication.

Using symbolic interactionism and the semiotic theories, the author will answer the problem of this paper, namely "What is the significance of the tu gelu healing method of the Lio people at Ngalukoja Village, Ende Regency, East Nusa Tenggara?" Meanwhile, the aim is to know the significance of the tu gelu healing method.

\section{Methods}

This research was conducted at Ngalukoja Village, Ende Regency, East Nusa Tenggara, Indonesia, from February to June 2019. This is a descriptive qualitative research with a phenomenological paradigm that emphasizes the originality and the naturalness of the data sources. It assumes that visible behaviors are merely symptoms of the things hidden in the actors' minds [10]. These behaviors may only be understood if they uncover the things hidden in the conscious realm of the human [11]. The descriptive method aims to systematically, factually, and accurately describe analyzed phenomena through some stages: (1) data collection, (2) data analysis, and (3) result presentation [12].

In qualitative research, the data are analyzed using the inductive method. This research does not test the hypothesis, but it is only used as a guide. It tends to be more of an abstraction formation based on the collected data. The data are analyzed more intensively after all data are obtained in the field and those obtained in the research location are adequate and appropriate to be processed and arranged into research results up to the last stage, namely the conclusion.

Symbolic interactionism analyses qualitative data. Its primary data are obtained from informants in the field, namely those who understand the tu gelu traditional healing method. As based on Hamidi's opinion [13], informants must have special knowledge of the information required or they must directly be involved with the analyzed problem. In this case, the informants are the shaman, customary figures, and patients who have undergone the tu gelu treatment. The author acts as the key informant and the informants are selected using the snowball technique [14]. The data are collected using participative observation and in-depth interview methods [15].

The data are collected by two researchers (a chief researcher and a member). The researchers carry out in-depth interviews to the shaman (ata mbeo), social figures, and patients (ata robaja), and they carry out intensive observation on the sociocultural systems and the methods carried out by the shaman to the ill patients, including all items and materials used. The research is carried out one by one, starting from the shaman, nipi baro (fortune teller and astrologer), customary figures, social figures, patients, or sufferers using the snowball informant technique. It means that the interview is carried out to all available informants. However, if during the interview, there are the same answers and statements and are regarded as valid, a complete interview is not carried out. If there are data, words, oral statements, spoken words on procedures, healing systems, methods carried out, and items used to heal patients or sufferers that are the same, the answers that are the same are valid and they are not developed anymore. According to Albi Anggito and Johan Setiawan [16], this method is called researchers as key informants and as key instruments. This means that the researchers are the key informants who carry out observations and interviews to deepen understanding on the healing process to heal patients using the tu gelu method.

\section{Results}

\section{The Tu Gelu healing method}

The tu gelu healing method starts with the shaman (ata mbeo) asking the patient about their activities before they experienced the illness, while the shaman makes the gesture with his hands (Figure 2).

It includes questions on where they went, who they met, and whether or not they saw some shapeshifting creatures. The shaman checks whether or not the 


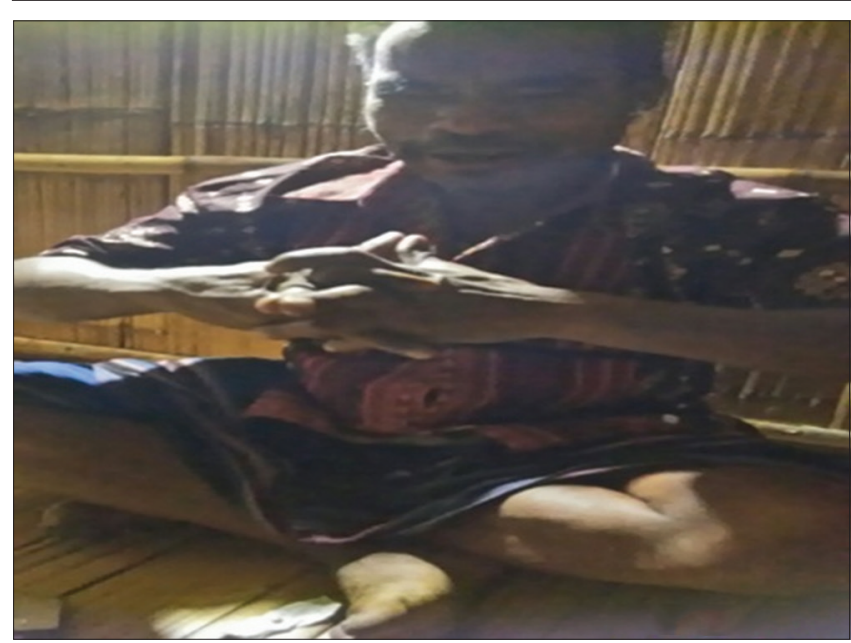

Figure 2: The shaman's gesture while he asks the patient's activities

patients become ill due to the disturbances of genies by measuring his chest to his right hand using the span of his left hand (paga) while reading spells (Figure 3 ).

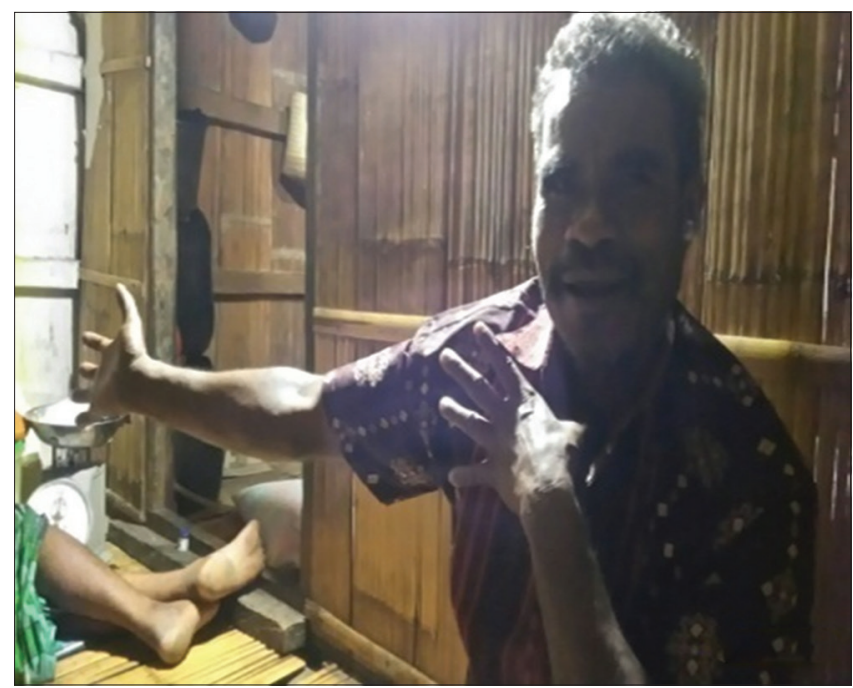

Figure 3: The shaman measures using the span of his hand

Then, the shaman measures the accuracy of the meeting between the two hands' fingers (Figure 4).

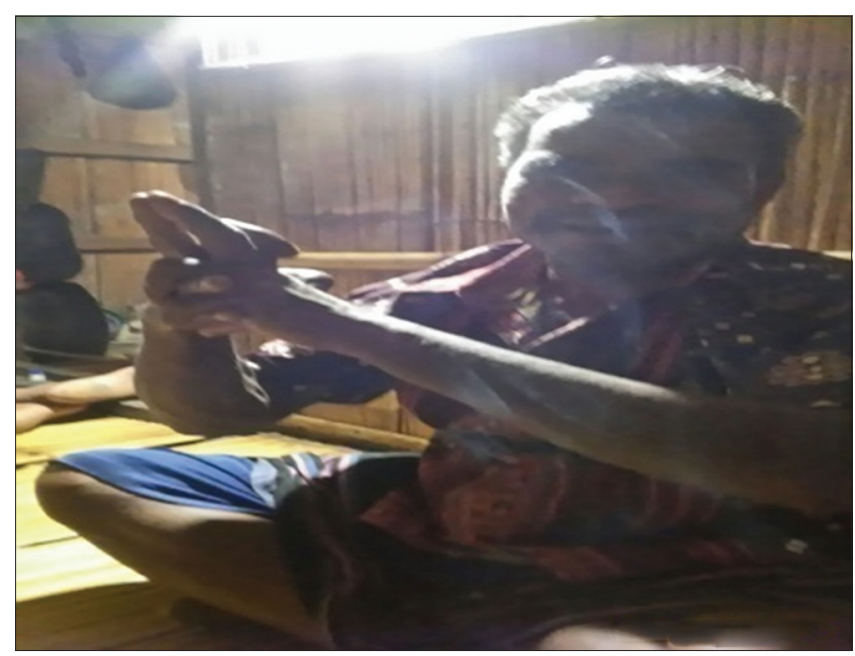

Figure 4: The shaman finds the cause of illness
If the person became sick due to the disturbances of genies, Satan, or evil spirits, the position of the fingers will appear like the gesture in Figure 3.

After this process, the patient must prepare some material things that symbolize humans or genies: Pandanus leaves, eggplant, sticks, container, golden coins from bananas, necklace from Pandanus leaves, white rice, banana slices that symbolize golden coins, a short tail that symbolizes pigs, a long tail that symbolizes bulls, and kitchen ash. They are put in the stick skrews to resemble cattle (pigs and bulls) (Figure 5).

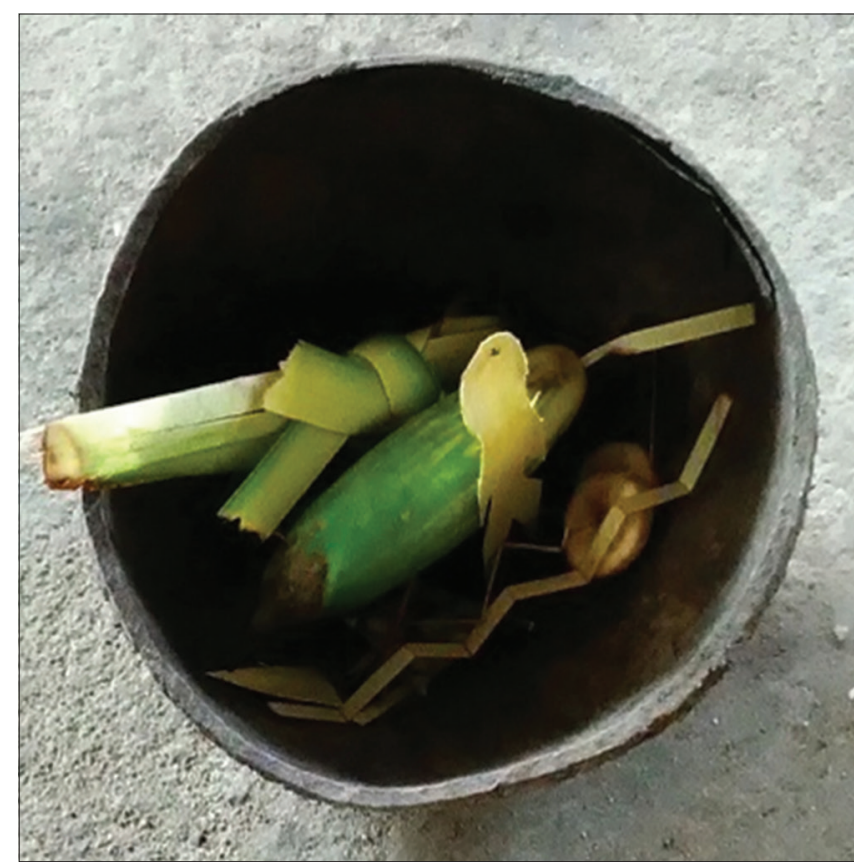

Figure 5: The items are placed in a container

According to the shaman, these components symbolize the close relations between humans, nature, living and non-living creatures. It means that humans must preserve nature to prevent destruction and to live well (Interview with Siprianus Ngae, April 19, 2020) (Figure 6).

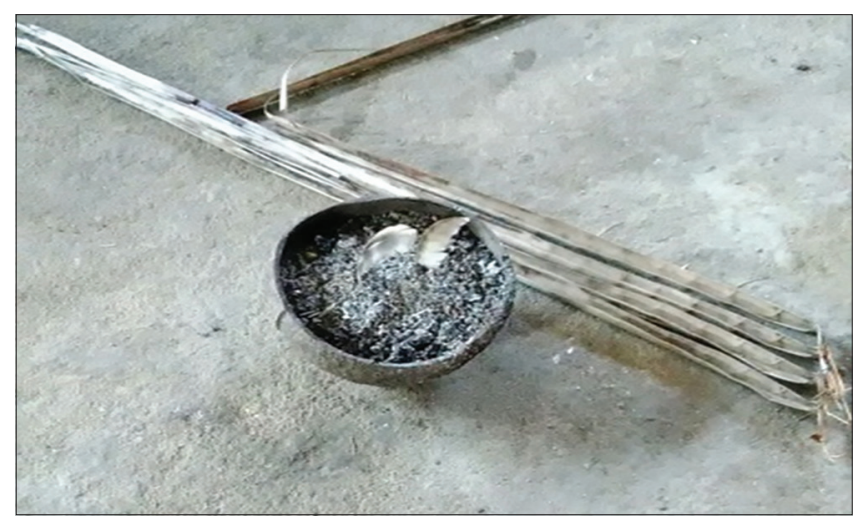

Figure 6: The container to burn incense

The shaman then brings the incense container and the items that symbolize cattle to the place where the genies reside. These items are used as offerings for the exchange (tu gelu) process. While bringing the offering, the shaman brings a machete that is covered 
with sarong and coconut shell, filled with kitchen ash, and with a chicken feather on top. The shaman then places these offerings on the ground where the genies reside, and the coconut shells are covered with leaves or sticks. He reads spells, asking for the genie to heal the sick.

While returning home, the shaman brings the machete to his left hand, meanwhile, his right fist is clenched. It is believed that he brings the soul of the sick in his right hand. At home, he opens the door and then closes it tightly. To heal someone with fever, he sits at the front of the patient, and wipes his right hand on the face of the patient to the toes, while saying, "Kau o, ndate menga o poru keta na aku mo joka wola sambu walo o petu gha tau keta rango menga to ngga (You, the sick, I have wiped you and I have asked your fever to cool and to revive the tired body)."

Meanwhile, to heal people who became sick after seeing human-like genies, the villagers believe that it is prohibited to use modern medical treatments, as it may cause death. Usually, people become sick after eating some food given by those genies that take the form of the people they love. They believe that they must use the tu gelu method to revive (Interview with Aksa Mage, May 3, 2019). The method of healing is the same as that of healing people with fever. The shaman also suggests the patients attack the human-formed genies so that the genies do not disturb them in future. People may also become sick if some illnesses are sent by other people using supernatural powers, where the sender may sacrifice his/her family member to inflict illnesses on other people (Interview with Petrus Poto, a shaman, on April 23, 2019). Generally, it is difficult to prove these supernatural occurrences. However, these villagers regard that it is rational to resolve their problems using mystical methods.

\section{Tu Gelu}

\section{The symbolic interactionism analysis of}

Symbolic interactionism states that humans interact using symbols that they produce and that are transferred to others [16]. Every community has its own material symbols which may have been socioculturally created centuries or millennia ago. In the tu gelu healing method, material symbols are exchanged with the patient's health, mediated by a shaman. This exchange revives those who are sick due to genies' disturbances, as their souls are taken and exchanged with items that resemble bulls and pigs.

\section{The semiotic analysis of Tu Gelu}

Peirce in Berger as stated by Aimi [17] and Sobur [18] states that signs are related to the objects they resemble. The objects have causal and conventional relationships with the signs. He uses the term icon for their similarities, index for the causal effect, and symbol for the conventional association.

\section{Icon}

The icon is a sign where there are similarities between the ground and the object. In this case, the icons are Figures 1-5. The items in the pictures are used to exchange for the ill person's soul so that he/ she is healed.

\section{Index}

The index is a sign that shows a causality effect. The shaman places the kitchen ash and the chicken feather to the genie that caused the sickness so that the patient's soul is returned. It is hoped that the offering blocks the genie from following the shaman home. Then, the spell, such as "Kau o, ndate menga o poru keta na aku mo joka wola sambu walo o petu gha tau keta rango menga to ngga (You, the sick, I have wiped you and I have asked your fever to cool and to revive the tired body)," serves as an index to heal the sick. Then, the spell, "Aku mo rongge ura lima demadema kai duru bai mai nitu pa'i, o ate rango ura lima na kau molo ura lima (I fold my fingers, if the patient is disturbed by an offended genie, the fingers will show five spans)," serves as an index to measuring the chest to the hand, to diagnose the cause of the patient's sickness. If there are five spans, the cause of the sickness is the genies' disturbances.

\section{Symbol}

A symbol signifies a conventional relation due to an agreement. The items in tu gelu that serve as symbols are shown in Table 1.

Table 1: The objects that serve as symbols

\begin{tabular}{|c|c|c|}
\hline No. & Object & What the object symbolizes \\
\hline 1 & Machete & Resistance against genies \\
\hline 2 & Leaves that cover the offering & $\begin{array}{l}\text { A boundary against so that the genies do not follow } \\
\text { the shaman home }\end{array}$ \\
\hline 3 & Kitchen ash & $\begin{array}{l}\text { A trap that hurts the genies' eyes if they try to follow } \\
\text { the shaman }\end{array}$ \\
\hline 4 & Chicken feather & A propeller that makes the ashes fly \\
\hline 5 & Coconut shell & The universe \\
\hline 6 & Pandanus leaves & Golden chips \\
\hline 7 & Banana slices & Silver \\
\hline 8 & Puppets from palm leaves & The soul of the sick \\
\hline 9 & Eggplants & $\begin{array}{l}\text { Cattle offered to the genies to exchange with the } \\
\text { soul of the sick }\end{array}$ \\
\hline
\end{tabular}

\section{Discussion}

Material things in the tu gelu healing method serve as signs to heal the sick. Using the symbolic interactionism analysis, it is shown that material symbols are exchanged with the patient's health. Their souls are taken and exchanged with items that resemble bulls and 
pigs. Then, using the semiotic theory, it is shown that the figures serve as icons, as items in the pictures are used to exchange for the ill person's soul. The kitchen ash and the chicken feather serve as indexes to prevent the genies from following the shaman. Spells also serve as indexes to heal the sick. Finally, the items prepared as the offering to the genie serve as symbols, as shown in Table 1.

\section{Conclusion}

Tu gelu is a traditional medical treatment to heal the sick by exchanging items that symbolize certain things with the sick's soul. This act is mediated by the shaman, who diagnosed the illness through paga, or by measuring the chest to the right hand using the span of the left hand. Each of the exchanged items contains symbolic meanings, as analyzed using semiotics and the symbolic interactionism theories in this paper. The Ngalukoja villagers of East Nusa Tenggara believe that by using the tu gelu healing method, the patient will fully revive from the illness.

\section{References}

1. Sarwono S. Sociology of Health. Yogyakata: Gajah Mada University Press; 2017.

2. Foster GM, Anderson BG. Antropologi Kesehatan. Translated Anthropology of Health. Jakarta: Universitas Indonesia Press; 2009.
3. Soekanto S. Introduction to Sociology. Jakarta: Raja Grafindo Persada; 2011.

4. Barker C. Cultural Studies, Theory and Practice. Translated Teori dan Praksis. Yogyakarta: Bentang; 2008.

5. Hoed HB. Semiotics and Socio-Cultural Dynamics. Depok: Komunitas Bambu; 2011.

6. Poloma M. Contemporary Sociological Theory. Translated Sosiologi Kontemporer. Jakarta: Penerbit Raja Grafindo Persada; 2007.

7. Blumer H. Symbolic Interactions. Translated Interaksi Simbolis. Jakarta: Raja Grafindo Persada; 2014.

8. de Saussure F. Cours de Linguistique Générale. Translated Kursus Linguistik Umum. Yogyakarta: UGM Press; 2013.

9. Danesi M. Message, Sign, and Meanings, A Basic Textbook in Semiotic and Communication Theory. Yogyakarta: Penerbit Jalasutra; 2004.

10. Wignjosoebroto $S . C Q$ social reality phenomenon as an object of social (studies) analysis object. In: Bungin B, editor. Qualitative Research Method: Methodological Actualization towards Contemporary Variant. Jakarta: Raja Grafindo Persada; 2001. p. 16-22.

11. Bungin B. Mass Media Image. Yogyakarta: Jendela; 2001.

12. Mulyana D. Qualitative Research Methodology: ANew Paradigm of Communication and Other Social Science Studies. Bandung: PT Remaja Rosdakarya; 2001.

13. Hamidi. Qualitative Research Method. Malang: UPT Universitas Muhammadiyah Malang; 2008.

14. Muhadjir N. Qualitative Research Method. $4^{\text {th }}$ ed. Yogyakarta: Penerbit Rake Sarasin; 2000.

15. Spradley JP. Method of Ethnography. $5^{\text {th }}$ ed. London: Paperback; 1997.

16. Anggito A, Setiawan J. Metodologi Penelitian Kualitatif. Sukabumi: Jejak Publishers; 2018.

17. Aimi S. Memahami teori konstruksi sosial peter L. Berger. Society. 2016;4(1):1.

18. Sobur A. Ethics of the Press: Professionalism and Conscience. Bandung: Humaniora Utama Pres; 2001. 